\title{
DESCRIPCIÓN DE LA MENTIRA
}

Julio LLAMAZARES

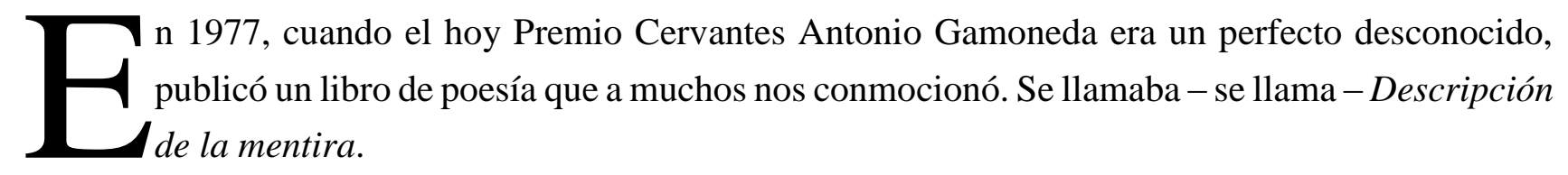

Cuando apareció ese libro, Antonio Gamoneda llevaba 17 años sin publicar. Así que, para los jóvenes como yo era entonces, como para la mayoría de los que lo leyeron, Descripción de la mentira supuso todo un descubrimiento. Se trataba de una poesía distinta, hermética, pero bellísima, y, sobre todo, llena de interpretaciones. No hace falta que yo diga que para mí aquel libro sería fundamental.

Sé que a Antonio Gamoneda, tan poco amigo de las simplificaciones, la lectura que algunos hicimos entonces de su libro no le agradaría mucho, aunque, con su buen estilo, nunca dijo nada en contra. Me refiero a esa lectura que identificaba un tanto simplistamente (era la época y era también nuestra ingenuidad) la mentira del título de su libro con la que este país había vivido durante años. A través de ella, versos como el que abre el texto - «El óxido se posó sobre mi lengua como el sabor de una desaparición / El olvido entró en mi lengua y no tuve otra conducta que el olvido / y no acepté otro valor que la imposibilidad»- cobraban a nuestros ojos un sentido muy directo, tan directo quizá como distinto al que el poeta había querido darles. Y no digamos aquellos otros que expresamente apuntaban: «Los que sabían gemir fueron amordazados por los que resistían la verdad, pero la verdad conducía a la traición / Algunos aprendieron a viajar con su mordaza y éstos fueron más hábiles y adivinaron un país donde la traición no es necesaria: un país sin verdad». Esto, para mí y para mis amigos, en aquel año de 1977, era toda una declaración.

Recordaba todo eso mientras Antonio Gamoneda, con su educación antigua, leía su discurso sobre la poesía y la pobreza delante de un auditorio -el de los premios Cervantes, en Alcalá de Henares- la mayoría del cual seguramente no sabía quién era hasta ese día y me venía a la cabeza aquella lejana época en la que yo pensaba que la mentira era algo del pasado, algo que afortunadamente se terminaba por fin en este país. ¡Qué ingenuos éramos todos!. ¿Qué infelices creyendo que aquel libro que leíamos como si fuera una revelación no era una visión del mundo, sino el epitafio de una época concreta!.

Aquel país ha cambiado mucho, pero los versos de Gamoneda siguen vigentes, por desgracia para nosotros. Y continuarán estándolo, me temo, habida cuenta de hasta qué punto la mentira ha 
arraigado en nuestros comportamientos, sobre todo en los de la vida pública. Basta leer los periódicos, mirar las televisiones, escuchar los discursos de nuestros dirigentes o los debates de los opinadores para ver cómo esa palabra, la mentira, es la más utilizada por todos ellos, eso sí, atribuyéndosela siempre al otro. $\mathrm{Y}$ lo peor es que esas acusaciones ni siquiera se toman en serio, al menos no como para denunciarlas (en el caso, claro está, de que fueran infundadas), como si la acusación de mentir fuera algo natural, tan natural como la mentira en sí. Al fin y al cabo, se justifica, éste es el país de la picaresca.

Desde hace tiempo, esa situación se ha acentuado hasta el punto de que continuamente nuestros políticos se acusan mutuamente de mentir, cuando no mienten abiertamente, como ocurrió con el 11M. Que alguien lo haga es ya grave en sí, pero más grave es la impunidad con la que tal comportamiento es tomado por el resto, impunidad que lleva a algunas personas (el expresidente Aznar, a propósito de los motivos para la invasión de Irak, por ejemplo) a reconocer que mintieron o que no dijeron la verdad completa sin dimitir a continuación ni pedir perdón a los ciudadanos, como si el solo reconocimiento de la mentira bastase para borrarla de sus currículums y sus efectos de la vida de la comunidad. Eso cuando no se da un salto adelante y se pretende borrar la mentira con otra nueva, como ahora hacen quienes nos niegan que durante varios años han sostenido, incluso contra las pruebas, que los autores de la matanza del 11-M la ejecutaron en colaboración con ETA. Doble mentira que ofende aún más, por cuanto la primera se agranda con la segunda, como ocurre con esos errores que se pretenden subsanar con otros.

Seguimos, pues, nadando en el mismo fango que el poeta Gamoneda describía hace tres décadas ( «El silencio y sus círculos, el ácido que depositas sobre mi salud/la suciedad obligatoria de mi alma: este es el precio de la paz»), sólo que ahora sabiendo que eso es así. Ahora no hay velos que disimulen la mentira y el engaño, como antes, pese a lo cual ambos continúan vigentes. Y continúan vigentes por lo que he dicho: porque nos hemos acostumbrado a mentir y a que nos mientan, porque la mentira aquí no tiene el rechazo que en otras partes, porque en la patria de la picaresca no está mal visto -al revésengañar al oponente, siempre y cuando se haga con gran cinismo, porque la mentira, en fin, forma parte de nuestra idiosincrasia, especialmente de la de aquéllos que aprendieron a mentir en los tenebrosos años en los que «los que sabían gemir fueron amordazados por los que resistían la verdad».

Dicen los historiadores que los efectos de una dictadura tardan décadas en desaparecer y el ejemplo quizá sea España. Aunque mucha gente sostenga que estamos homologados con los países de nuestro entorno, aunque nuestra economía crezca pujante, por delante incluso de las de aquéllos, aunque, desde hace ya tiempo, el ejercicio de la política se atenga a las normas de la democracia, todavía arrastramos un déficit de normalidad que hace que sobrevivan entre nosotros comportamientos pertenecientes a otros sistemas y que ello se contemple con cierta indiferencia por la gente. Debe de ser la costumbre. Vuelvo a los versos de Gamoneda, aquéllos que yo leía a finales de los 70 como si fueran una revelación: «De la verdad no ha quedado más que una fetidez de notarios / una liendre lasciva, lágrimas, orinales /y la liturgia de la traición (...) / ¿Qué lugar es éste, qué lugar es éste?». 